\title{
Rezim Global dan Liberalisasi Perdagangan Sektor Garam di Indonesia
}

\author{
Esti Renatalia Tanaem \\ Alumni S2 Ilmu Hubungan Internasional \\ Universitas Gadjah Mada \\ Puguh Toko Arisanto \\ ptas002@gmail.com
}

Dosen Ilmu Hubungan Internasional, Universitas Teknologi Yogyakarta

Received: 01 Juli 2020; Revised: 10 Juli 2020; Accepted : 20 Juli 2020; Published : Agustus 2020; Available online : Agustus 2020.

\begin{abstract}
Known as a maritime country, Indonesia is still unable to meet its need of salts, especially industrial salts. As a result, Indonesia has to import salts from various countries with an increasingly higher volume each year. Using theory of two-level games, authors found that the salt importing policy cannot be separated from international pressures so that Indonesia undertakes trade liberalization on salt sector. The international pressure emanated from three global regimes namely WTO, IMF and FTA. The three global regimes basically require Indonesia to liberalize its domestic market by removing tariff and non-tariff trade barriers in various sectors including salt. This paper will explain the mechanism and scheme of the three global regimes in liberalizing Indonesia's trade on salt sector.
\end{abstract}

Keywords: Import Salt, International Pressure, Trade Liberalization, Global Regimes 


\section{Pendahuluan}

Indonesia dikenal sebagai negara maritim memiliki garis pantai dengan panjang sekitar 99.093 kilometer. Dengan garis pantai yang hampir mencapai 100.000 kilometer, Indonesia menduduki sebagai negara dengan garis pantai terpanjang kedua di dunia setelah Amerika Serikat (AS) (Kementerian Kelautan dan Perikanan, 2018). Indonesia juga memiliki wilayah perairan yang mencapai $2 / 3$ dari wilayah daratannya atau sekitar 5,8 juta kilometer. Jika Indonesia mampu memanfaatkan dan mengelola wilayah kelautannya yang menyimpan kekayaan alam dalam jumlah yang luar biasa secara maksimal, Indonesia diperkirakan mampu meraup pendapatan sebesar US\$ 1,2 triliun dollar per tahun (Taufikurohman, 2016). Dalam konteks lain, dengan garis pantai yang sangat panjang dan wilayah perairan yang luas Indonesia dianugerahi kekayaan air laut yang berpotensi untuk dijadikan garam dengan jumlah yang sangat melimpah.

Meskipun demikian, Indonesia sepertinya masih mengidap penyakit umum di kebanyakan negara berkembang yakni Paradox of Plenty. Kekayaan tersebut belum mampu dimanfaatkan Indonesia untuk swasembada garam khususnya untuk garam industri guna memenuhi kebutuhan domestiknya. Ini berarti bahwa Indonesia masih belum mampu memaksimalkan potensi wilayah perairan lautnya secara maksimal untuk menghasilkan garam dalam jumlah yang melimpah maupun garam yang berkualitas. Konsekuensinya adalah Indonesia harus mengimpor garam baik garam konsumsi maupun garam industri dari negara lain yang notabene tidak memiliki endownment berupa kekayaan laut sebanyak Indonesia. Negara-negara pengimpor garam ke Indonesia yaitu Australia, India, Tiongkok, Selandia baru, Singapura dan sebagainya.

Berbagai program untuk mengurangi ketergantungan impor garam dengan telah digalakkan oleh pemerintah Indoensia, khususnya kementerian Kelautan dan Perikanan (KKP). Salah satunya adalah dengan menjalankan Program Pemberdayaan Usaha Garam Rakyat (PUGAR) yang terbentuk sejak tahun 2011 pada masa pemerintahan Susilo Bambang Yudhoyono. Beberapa tujuan PUGAR yakni meningkatkan produktivitas dan kualitas garam lokal, meningkatkan petambak lokal dan mengoptimalkan sarana prasarana produksi dan pengolahan garam rakyat (Apriela, 2016). Kemudian program tersebut juga 
dilanjutkan oleh Menteri KKP, Susi Pudjiastuti pada era pemerintahan Jokowi. Selain itu, sebelum PUGAR terbentuk, Kementerian Perindustrian (Kemenperin) pada tahun 2009 juga telah membentuk program klaster industri garam 2009-2014 yang bertujuan untuk memenuhi kebutuhan aneka industri dan konsumsi garam nasional, meningkatkan produksi garam nasional, menurunkan volume garam impor dan terdistribusinya volume garam beryodium yang memenuhi persyaratan (Kemenperin, 2009). Meskipun berbagai program telah dijalankan namun faktanya Indonesia masih belum bisa melepaskan ketergantungannya terhadap garam impor. Volume impor garam mengalami kenaikan dari tahun ke tahun. Sebagai contohnya, pada tahun 2020 Indonesia mengimpor sebanyak 2,92 juta ton atau naik sekitar 6\% dari tahun 2019 yang mencapai 2,75 juta ton untuk memenuhi kebutuhan garam Industri domestik. Sementara itu produksi garam lokal untuk kebutuhan industri domestik masih belum bisa memenuhi persyaratan kualitas yang tinggi dan dengan jumlah yang besar (Sandi, 2020).

$$
\text { Penulis melihat bahwa }
$$
ketergantungan Indonesia terhadap impor garam industri selain dikarenakan adanya pergolakan politik diantara para birokrat seperti KKP, Kemenperin dan Kementerian Perdagangan (Kemendag) dan mafia garam, juga dikarenakan adanya pengaruh dari adanya liberalisasi perdagangan yang mencengkram kebijakan domestik Indonesia. Liberalisasi perdagangan dalam konteks ini dapat diartikan sebagai pengurangan maupun penghapusan trade barriers (hambatan-hambatan) perdagangan baik berupa tarif maupun non tarif. Instrumen liberalisasi perdagangan dapat berbentuk seperti pengurangan atau penghapusan tarif, pengurangan atau penghapusan kuota impor dan pengurangan hambatan non-tarif (Banton, 2019). Indonesia telah melakukan liberalisasi perdagangan di sektor garam yang dibuktikan dengan adanya penurunan bea masuk garam impor dari tahun ke tahun dengan persentase sebesar 5\%-10\% (versi Kementerian Keuangan). Sementara itu, peraturan Peraturan Menteri Perdagangan (Permendag) Nomor 88 Tahun 2015 menyatakan bahwa bea masuk garam impor untuk tujuan Industri yakni 0\% (Kemenperin, 2015). Bea masuk 0\% menegaskan bahwa Indonesia telah mengadopsi liberalisasi perdagangan di sektor garam nasional. Dengan adanya tarif yang hanya $0 \%$ dan 
produksi garam industri yang masih minim tidak mengejutkan lagi jika komoditas garam impor membanjiri pasar domestik Indonesia.

Berbicara mengenai faktor internasional penulis melihat bahwa liberalisasi perdagangan di sektor garam nasional tidak bisa dilepaskan dari rezim-rezim global yang memberikan tekanan agar Indonesia mengadopsi dan menerapkan liberalisasi perdagangan, salah satunya di sektor garam. Rezimrezim global tersebut membawa seperangkat norma, peraturan dan prosedur pengambilan kebijakan yang mempengaruhi pengambilan kebijakan di lingkungan domestik Indonesia. Dalam kasus liberalisasi perdagangan di sektor garam nasional, penulis mencatat ada tiga rezim global yang terlibat yaitu World Trade Organization (WTO), International Monetery Fund (IMF) dan Free Trade Area (FTA). Oleh karena itu, tulisan ini menjelaskan mengenai tekanan Internasional yang berasal dari tiga rezim global tersebut dalam politik liberalisasi perdagangan di sektor garam nasional.

\section{PEMBAHASAN}

\section{Ratifikasi Perjanjian World Trade} Organization

Perdagangan

internasional dipercaya dapat membawa kemakmuran bagi negara-negara dari waktu ke waktu sehingga barriers (hambatan-hambatan) baik berupa tarif maupun non tarif dalam perdagangan semakin dikurangi. Untuk mewujudkannya, dibentuklah sebuah institusi yang disebut dengan WTO sebagai rezim perdagangan dunia untuk mengurangi hambatan-hambatan tersebut. Perdagangan dunia berkembang dengan sangat pesat pada 60-70 tahun terakhir ini. Kebanyakan ahli politik yang mempelajari mengenai ekonomi global percaya bahwa perdagangan dunia tidak akan berkembang sepesat ini jika WTO tidak pernah dibentuk setelah Perang Dunia ke II.

Sebelum dibentuknya WTO, pada tahun 1947 hingga 1994 General Agreement on Tariff and Trade (GATT) telah memainkan peran sebagai rezim perdagangan global seperti WTO. Tahun 1995, WTO dibentuk dan GATT tetap diadopsi sebagai substansinya. Pembentukan WTO didasarkan pada dua prinsip utama WTO yakni liberalisme pasar dan nondiskriminasi. Liberalisme pasar menegaskan bahwa sistem perdagangan internasional yang terbuka atau liberal dapat meningkatkan standar hidup. Pencapaian utama dari perdagangan adalah ketika barang dapat dengan mudah bergerak melewati batas 
negara dengan leluasa tanpa hambatan dari pemerintah. Sedangkan nondiskriminasi memastikan bahwa setiap anggota WTO memiliki kesempatan yang identik untuk berdagang dengan anggota lainnya. Prinsip nondiskriminasi terbagi dalam dua bentuk yaitu Most-Favored Nation (MFN) yang melarang pemerintah untuk menggunakan kebijakan perdagangan yang menyediakan manfaat khusus bagi negara-negara tertentu dan tidak bersikap yang sama untuk negara-negara lain. Dengan kata lain, semua negara anggota diperlakukan sama. Kedua, National Treatment mewajibkan pemerintah untuk memperlakukan barang yang sama (like product) secara identik ketika barang dari negara anggota lain memasuki pasar domestik (Oatley, 2019).

Indonesia turut menjadi anggota WTO bahkan jauh sebelum WTO terbentuk tepatnya ketika perdagangan internasional masih menggunakan GATT. Indonesia meratifikasi perjanjian WTO melalui UU No. 7 Tahun 1994 sehingga Indonesia legally binding dengan segala peraturan yang disepakati dalam WTO. Karena di WTO berlaku prinsip singleundertaking pinciple, Indonesia tidak bisa menjalankan ketentuan yang dirasa menguntungkan dan mengabaikan ketentuan yang dirasa merugikan. Dalam konteks hukum, sekali Indonesia meratifikasi ketentuan WTO, maka Indonesia meratifikasi belasan perjanjian atau persetujuan yang ada di dalamnya. Dalam konteks hukum internasional, ketentuan-ketentuan WTO memiliki bentuk legalisasi hard law. Dengan adanya legalisasi ini, pelanggaran atas ketentuan WTO dapat digugat oleh negara lain dan diadili di Dispute Settlement Body (DSB) WTO (Abbott \& Snidal, 2000).

Dari belasan perjanjian di WTO, salah satu perjanjian yang paling mendapatkan perhatian oleh Indonesia sebagai negara pertanian dan maritim adalah Agreement on Agriculture (AoA). AoA merupakan salah satu dari dua perjanjian utama yang dibahas di Uruguay Round (1986-1994) selain Agreement on Textiles. Sebagaimana perjanjian WTO lainnya, AoA juga mengikat seluruh anggota WTO. Implementasinya berbeda-beda yaitu negara maju diberi waktu hingga tahun 2000 untuk mengimplementasikan komitmennya sedangkan negara berkembang hingga tahun 2004. AoA dipredikasi memberikan dampak membanjirnya produk pangan impor di negara berkembang. Hal ini disebabkan karena penurunan tarif yang dilakukan 
oleh negara berkembang sehingga tidak dapat memberikan perlindungan bagi produsen domestik (Glipo, 2003).

Melalui perjanjian AoA ini, Indonesia diharapkan bahkan diwajibkan untuk menghapus tarif dan subsidi pertanian sehingga produk impor dapat bersaing di pasar domestik Indonesia. Dengan adanya perjanjian ini, bukanlah hal yang baru jika produk impor membanjiri pasar domestik Indonesia dan produk dalam negeri tidak mampu bersaing dengan produk impor tersebut. Pada akhirnya negara harus terus mengimpor (Delforge, 2005). Inilah yang terjadi di Indonesia terkhusus komoditas garam yang termasuk dalam bidang pertanian di perjanjian ini

Fadel Muhammad, Menteri Kelautan dan Perikanan Era Susilo Bambang Yudhoyono, menyatakan bahwa Indonesia sebagai negara agraris yang tidak mampu untuk swasembada pangan dikarenakan pengaruh dari skema liberalisasi perdagangan di sektor pertanian WTO (Setiawan, 2013). WTO dipersepsikan sebagai alat kendali negara-negara maju terutama AS dan Uni Eropa agar negara-negara berkembang selalu berada didalam pengaruh mereka. Hampir semua negara berkembang menggantungkan kehidupan pada sektor pertanian namun terancam karena meratifikasi AoA seperti yang direkomendasikan oleh WTO. AoA diklaim merupakan permasalahan utama dalam WTO yang menyebabkan ditahun 2012 Indonesia mengeluarkan lebih dari 125 triliun untuk mengimpor komoditas pangan termasuk garam yang semakin mematikan pertanian Indonesia. Liberalisasi di sektor pertanian ini sangat berdampak pada proses impor pangan (Sulaiman, 2013).

WTO dikatakan sebagai institusi yang memiliki kekuasaan untuk mewajibkan negara-negara anggota agar melaksanakan kesepakatan-kesepakatan yang ada. Sebagai anggota, kebijakan pertanian Indonesia harus diselaraskan dengan AoA (Khudori, 2004). Ini diperburuk dengan ketiadaan strategi dan arah kebijakan dalam perdagangan multilateral terutama AoA yang membuat sektor pertanian Indonesia makin buruk. Pemerintah tidak melakukan studi atas implementasi AoA pada sektor pertanian padahal survei Food and Agriculture Organization (FAO) pada pengalaman 14 negara berkembang yang menjalankan AoA periode 19951998 menunjukkan hasil yang tidak baik. Sebelum perjanjian AoA, Indonesia adalah eksportir beras ke 9 di dunia. Tiga tahun setelah AoA (1998), Indonesia tidak lagi menjadi negara eksportir 
namun menjadi importir beras pertama di dunia (Khudori, 2004). Hal yang sama juga terjadi pada komoditas garam.

\section{Menurut Direktur Eksekutif} Indonesia for Global Justice (IGJ), Riza Damanik, keikutsertaan Indonesia dalam WTO justru melemahkan daya saing dan menimbulkan praktek korupsi terkait impor pangan (Tempo, 2013). Pasalpasal dalam WTO menggerus kedaulatan pangan karena persaingan dalam perdagangan bebas yang tidak sehat. Konsekuensinya adalah pemerintah Indonesia tidak dapat memberikan perlindungan bagi petani. Hal ini berdampak pada produk petani Indonesia termasuk garam yang kalah bersaing dengan produksi impor. Selama ini kontribusi petani bagi pembangunan nasional tergolong kecil yang apalagi didukung dengan perjanjian WTO ini.

\section{Grafik 1. Data Impor Garam Indonesia} 1998-2007.

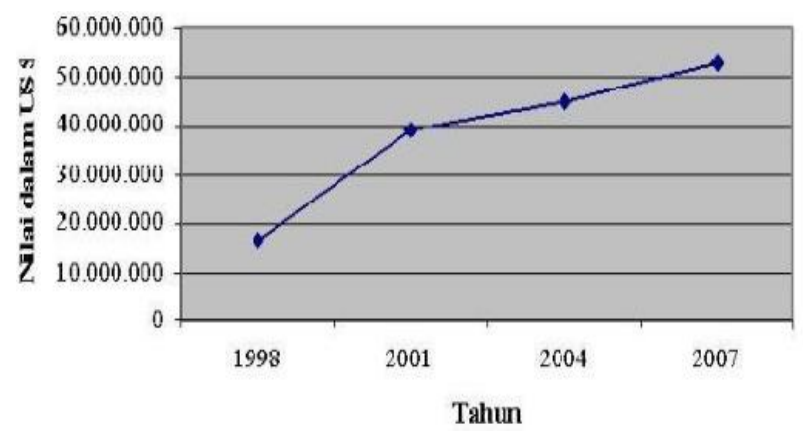

Sumber: Rochwulaningsih, 2012.

Sejalan dengan tujuan AoA untuk menghapus tarif agar produk impor dapat bersaing dan kebijakan pemerintah orde baru yang tidak menganggap garam sebagai komoditas strategis seperti yang dilakukan pemerintah kolonial Belanda maka Indonesia pun mulai mengimpor garam hingga saat ini. Penurunan bahkan penghapusan tarif impor sebagai bentuk liberalisasi perdagangan untuk mengurangi hambatan dalam perdagangan merupakan alasan atas membanjirnya garam impor di pasar domestik Indonesia. Hal ini disebabkan karena WTO dengan prinsip liberalisme pasarnya dan juga AoA yang bertujuan untuk menghapus tarif agar produk impor dapat bersaing. Di Indonesia, membanjirnya garam impor karena sudah meratifikasi WTO sehingga segala perjanjian didalamnya termasuk AoA sudah mengikat secara hukum. Selain itu, ini juga diperburuk dengan perbedaan kepentingan antar kementerian yang mengeluarkan tarif sehingga impor garam dilakukan dengan alasan untuk memenuhi kebutuhan garam domestik yang belum bisa dipenuhi oleh garam rakyat dan juga untuk memenuhi kepentingan elit politik dari pihak-pihak terkait.

Keikutsertaan Indonesia dalam WTO bukanlah sesuatu yang keliru asalkan pemerintah berupaya dengan serius untuk meningkatkan daya saing 
produk dalam negeri. Pemerintah tidak dapat melarang garam impor masuk ke Indonesia karena dalam WTO, karena selain dapat digugat oleh negara lain dan diadili di Dispute Settlemen Body (DSB), sengketa berupa retaliasi juga sangat mungkin terjadi. Retaliasi merupakan tindakan pembalasan dibidang perdagangan antar negara dalam kerangka WTO yang dilakukan oleh suaru negara sebagai akibat dari tidak tercapainya suatu kesepakatan dalam proses penyelesaian sengketa (Pelawi, 2007).

\section{Kewajiban Structural Adjustment} Program oleh International Monetary Fund

Pembentukan IMF dimaksudkan untuk menstabilkan mata uang serta menyediakan pinjaman jangka pendek. IMF memberikan pinjaman kepada negara-negara yang kesulitan membayar utang. Dana yang digunakan berasal dari berbagai bank internasional dan pemerintah negara-negara maju. Mekanisme ini memberikan IMF posisi yang kuat untuk memaksakan Structural Adjustment Program (SAP) kepada negara yang diberi bantuan termasuk Indonesia. Indonesia yang pada masa 1997-1998 dilanda krisis ekonomi sehingga utang luar negeri Indonesia memumbung akibat melemahnya rupiah.
Bantuan datang dari IMF dan diterima oleh Indonesia melalui pemerintahan Presiden Soeharto namun dengan syarat berbagai perubahan kebijakan termasuk sektor pertanian (Khudori, 2004). SAP berisi mekanisme-mekanisme berikut:

1. Penghapusan bea masuk (tarif), kuota, serta hambatan lainnya yang melindungi industri-industri kecil lokal agar tetap mampu bertahan hidup berhadapan dengan perusahaan-perusahaan besar global. Mekanisme ini untuk memudahkan integrasi global.

2. Penghapusan berbagai peraturan dalam negeri yang dianggap menghambat serta terlalu banyak mengatur masuknya investasi luar negeri.

3. Penghapusan kontrol harga bahkan harga pokok seperti pangan dan air

4. Pengurangan secara drastis berbagai pelayanan sosial

5. Penghancuran secara agresif program-program rakyat yang menjadi sarana bagi bangsa untuk mencapai kemandirian dalam hal kebutuhan pokok misalnya pangan

6. Pemaksaan perubahan secara cepat atas perekonomian dalam negeri untuk menekankan produksi ekspor. Dalam hal ini, produksi lokal berskala kecil dalam bidang industri atau 
pertanian dihentikan dan digantikan dengan produksi berskala besar (Khudori, 2004).

Mekanisme SAP ini merupakan syarat mutlak yang harus diterima dan dijalankan agar Indonesia mendapat bantuan dana. Keputusan yang dibuat oleh Presiden Soeharto untuk menerima bantuan dari IMF memaksa Indonesia untuk menandatangani segala ketentuan SAP yang diajukan oleh IMF agar menerima bantuan karena terjadi krisis. Ini adalah momen di mana Indonesia mulai melakukan deregulasi yang menyetujui penghapusan tarif agar mendapat pinjaman dari IMF. Setelah IMF memberikan bantuan untuk menyelamatkan krisis keuangan Indonesia pada tahun 1997-1998 tersebut, rezim perdagangan Indonesia menjadi lebih terbuka. Tingkat proteksi pasar domestik berubah terlebih ketika krisis melanda. Program penyesuaian struktural yang diajukan IMF mengharuskan adanya liberalisasi ekonomi (perdagangan) di Indonesia. Tahun 1998, perdagangan dalam negeri produk pertanian mengalami deregulasi bahkan hambatan non-tarif pun dihapus sebagai bentuk tindak lanjut dari liberalisasi perdagangan Indonesia (Baihaki, 2013). Setelah tahun 1998, Tingkat Ketergantungan Impor (TKI)
Indonesia sebagai net food importer country sejak 1994 meningkat dua kali lipat. Hal ini juga terjadi pada komoditas garam yang sejak tahun 1997 mengalami masa kejatuhan. Tahun 1998, Indonesia mulai mengimpor garam seiring dengan bertambahnya jumlah penduduk dan bertambahnya industri-industri yang memerlukan garam industri. Produksi garam rakyat tidak lagi mampu mencukupi kebutuhan domestik (Nurhayat, 2014).

Menurut Fadel Muhammad, selain WTO, IMF juga berperan pada proses liberalisasi perdagangan di sektor pertanian yang berdampak pada proses impor pangan (Sulaiman, 2013). SAP yang diwajibkan oleh IMF kepada Indonesia turut berdampak pada komoditas garam. Mekanisme SAP yang menuntut liberalisasi perdagangan menyebabkan adanya penghapusan tarif padahal tarif serta hambatan lainya merupakan pelindung bagi industri kecil lokal. Industri garam rakyat yang tidak berkembang merupakan akibat jangka panjang dari mekanisme-mekanisme SAP yang diterapkan oleh IMF. Salah satu mekanisme SAP menyebabkan biaya jaminan sosial untuk rakyat tidak lagi ditanggung pemerintah. Petani pun keluar dari desa dan beralih pekerjaan ke Jawa untuk mencukupi kebutuhan (Razif, 
2012). Produk-produk pertanian pun tidak lagi dapat mencukupi kebutuhan rakyat yang jumlahnya makin meningkat karena tidak ada kebijakan yang mendukung kemandirian pangan akibat mekanisme SAP. Bersamaan dengan itu, tarif impor pun dikurangi bahkan $0 \%$ untuk komoditas pokok seperti beras, gula, jagung, gandum/terigu dan kedelai (Khudori, 2004). Garam konsumsi pun saat ini $0 \%$ untuk tarif impor menurut skema tarif Kemendag. Penurunan bahkan penghapusan tarif ini pun diakibatkan karena SAP yang mewajibkan adanya penghapusan segala bentuk tarif, kuota dan hambatan impor lainnya.

\section{Ratifikasi Perjanjian Free Trade Area}

Selain menjadi anggota ASEAN Free Trade Area (AFTA) di kawasan Asia Tenggara, Indonesia juga meratifikasi beberapa perjanjian FTA dengan negaranegara di luar Asia Tenggara yaitu ASEAN-China Free Trade Agreement (ACFTA), ASEAN-India (AIFTA) dan ASEAN-Australia-Selandia Baru (AANZFTA) dan beberapa perjanjian FTA lainnya. Berdasarkan pasal XXIV GATT, Free Trade Agreement merupakan perjanjian antara dua atau lebih negara untuk menghapus hambatan-hambatan perdagangan baik tarif maupun non-tarif untuk semua barang secara substansial di antara mereka. Dalam FTA ini, negaranegara anggota sepakat untuk menetapkan tarif yang seragam untuk perdagangan antar anggota dan pada umumnya negara-negara saling menurunkan untuk produk-produk yang disepakatinya.

Indonesia meratifikasi ACFTA melalui Peraturan Presiden No. 48 Tahun 2004. Menurut beberapa studi mengenai ACFTA, Kebijakan liberalisasi perdagangan dalam ACFTA akan meningkatkan keterbukaan pasar yang akan berkontribusi positif terhadap pendapatan nasional dan pertumbuhan ekonomi, penciptaan lapangan pekerjaan dan pertumbuhan produktivitas. Pengurangan atau penghapusan tarif menyebabkan turunnya harga suatu produk sehingga dapat meningkatkan permintaan terhadap produk tersebut dan menyebabkan terjadinya penciptaan perdagangan baik dari peningkatan volume produk yang sudah diperdagangkan atau terciptanya pasar dari produk baru yang harga sebelumnya tidak terjangkau daya beli. Perjanjian Free Trade Agreement ini, memungkinkan produk dari negara Tiongkok membanjiri pasar domestik Indonesia. Tiongkok dan Indonesia dalam ACFTA ini sama-sama memetik hasil yang positif namun Tiongkok lebih 
dapat memanfaatkannya sehingga hasil yang didapat lebih optimal (Setiawan, 2013). Hal ini dapat dilihat dari membanjirnya produk Tiongkok di pasaran Indonesia termasuk garam.

Demikian juga dengan Indonesia yang meratifikasi perjanjian AIFTA dan AANZFTA. AIFTA mulai berlaku pada awal tahun 2010. Dengan adanya perjanjian ini, tarif impor produk pertanian, salah satunya adalah garam mengalami penurunan. Sedangkan AANZFTAdiratifikasi berdasarkan Peraturan Presiden (Perpres) No. 26 Tahun 2011. AIFTA dan AANZFTA yang juga mempromosikan liberalisasi perdagangan ini menghapus segala halangan dalam perdagangan baik tarif maupun non-tarif. Dengan diratifikasinya beberapa perjanjian FTA oleh Indonesia maka tarif diantara negara-negara yang terlibat dapat dihapuskan menjadi $0 \%$. Terjadi liberalisasi perdagangan disini melalui penghapusan tarif sehingga barang impor dari negara-negara yang melakukan perjanjian dapat masuk ke pasar domestik tanpa dikenakan tarif. Detailnya, Indonesia berkomitmen membebaskan tarif menjadi $0 \%$ kepada kurang lebih $85 \%$ dari pos tarif dari Australia dan New Zealand (Kemenkeu, 2012).
Dua perjanjian FTA tersebut memberikan dampak dalam waktu singkat. Badan Pusat Statistik (BPS) menunjukkan bahwa impor garam terbesar Indonesia berasal dari Australia dan disusul dengan India (Ariyanti, 2013). Kini Australia menjadi negara pengimpor garam terbesar untuk Indonesia karena didukung dengan teknologi yang canggih dalam produksi garam. Data di bawah ini menunjukkan bahwa Australia merupakan importir garam terbesar di Indonesia disusul dengan India dan Tiongkok dimana garam impor dari negara-negara ini pun membanjiri pasar garam domestik Indonesia.

Tabel 1. Negara Eksporter Garam

Terbesar di Indonesia 2009-2014

\begin{tabular}{|c|c|c|c|c|c|c|c|c|c|c|}
\hline \multicolumn{11}{|c|}{ 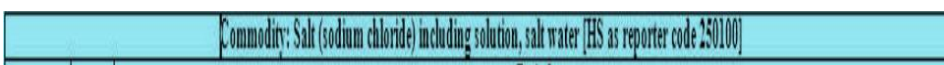 } \\
\hline \multirow{3}{*}{$\begin{array}{l}\text { Pintar } \\
\text { Courty } \\
\text { Vint }\end{array}$} & \multicolumn{10}{|c|}{ Pronde } \\
\hline & & (3) & & IIIIII & & & & 11114 & & 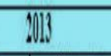 \\
\hline & $(s)$ & Qunitity & 100 & Pranitis & 150 & panitin & 150 & Qumining & 150 & Qumatity \\
\hline 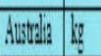 & 6009 & 139660134 & 8362626 & 1608000 & 1996659 & IXIMINW & 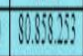 & 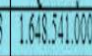 & 3151119 & 13851.42 \\
\hline What in & 101062 & J3966-4 & 1133600 & 866987 & 1509." & 102131386 & 133609 & 36.33000 & 1308966 & 163038000 \\
\hline (bing & in. 4 & $5199 \% \%$ & $(10461)^{6}$ & DIFWON & 3.8\% & 100.3 & 14S4H & 19098 & 6.1616 & WhW \\
\hline & & & & & & & & & & \\
\hline
\end{tabular}

Sumber: Data diolah dari UN Comtrade

Keikutsertaan Indonesia dalam perjanjian FTA disatu sisi dapat memberi keuntungan bagi Indonesia karena jika memanfaatkan comparative advantage yang dimiliki maka dapat meningkatkan kesejahteraan. Hal ini tidak terjadi pada produk garam yang mana Indonesia belum mampu untuk memanfaatkan 
faktor endowment yang dimiliki. Padahal sebagaimana dijelaskan dilatar belakang bahwa Indonesia dengan garis pantai terpanjang keempat didunia ini kaya akan air laut sebagai bahan baku pembuatan garam. Terikat dalam perjanjian-perjanjian FTA belum dapat dimanfaatkan sepenuhnya oleh Indonesia. Sudah ada usaha untuk mendukung produk-produk dalam negeri yang sejatinya memiliki keunggulan dengan mengeluarkan kebijakan-kebijakan yang dapat meningkatkan produktivitas agar dapat bersaing dengan produk dari luar akan tetapi masih belum maksimal.

Sisi positif dari FTA yaitu perluasan market access belum dimanfaatkan sepenuhnya terkhusus pada produk garam. Bahkan negara Australia dengan garis pantai hanya $26.059 \mathrm{~km}$ menjadi negara yang mengimpor garam terbesar ke Indonesia karena sudah memiliki teknologi yang canggih dalam pengolahan garam. FTA dapat meningkatkan akses pasar bagi negara-negara yang terlibat didalamnya namun dapat menghancurkan usaha kecil dan menengah. Hal ini menunjukkan bahwa selain belum dapat memanfaatkan faktor endowment yang dimiliki, Indonesia juga belum dapat mengembangkan usaha kecil termasuk para kelompok petani garam yang mana usaha mereka tergolong dalam usaha kecil. Para kelompok petani ini mengaku kekurangan modal sementara untuk meminjam di bank karena mereka tidak berani walau melalui Kredit Usaha Rakyat (KUR). Sementara itu, koperasi pun tidak berjalan dengan baik. Salah satunya adalah koperasi usaha garam di Nusa Tenggara Timur (Esterlina, 2014).

Menurut Henry Saragih, Ketua Umum Serikat Petani Indonesia (SPI), FTA memperburuk tingkat kesejahteraan ekonomi petani dan usaha kecil menengah (UKM). Semisal ACFTA yang setelah satu tahun perjanjian ini dilaksanakan, produk pangan dari Tiongkok membanjiri pasar domestik (Serikat Petani Indonesia, 2011). Ini adalah akibat dari ratifikasi perjanjianperjanjian tersebut sehingga tarif berbagai komoditas termasuk garam menjadi 0\%. Walaupun mematikan garam rakyat namun ini tidak bisa dilarang karena Indonesia sudah meratifikasinya melalui undang-undang.

\section{Rezim Global Sebagai Bentuk Tekanan Internasional dalam Liberalisasi Perdagangan Di Sektor Garam Nasional}

Robert D. Putnam (1988) melalui teori two-level games, menyatakan bahwa adanya entanglement (keterkaitan) antara politik domestik dan 
hubungan antar negara. Interaksi mereka bisa bersifat saling mempengaruhi. Purnam menegaskan bahwa selain dihadapkan pada tekanan domestik dalam proses politik pengambilan kebijakan, pengambil kebijakan juga dihadapkan pada tekanan internasional. Oleh karena itu, kebijakan dalam negeri maupun luar negeri tidak jarang dibuat (salah satunya) untuk memenuhi tekanan internasional. Tekanan internasional bisa berasal dari negara lain, International Government Organizations (INGOs) maupun International government organization (IGOs) organisasi-organisasi internasional atau yang biasanya diistilahkan sebagai rezim global atau internasional. Menurut Krasner (1983), rezim merupakan seperangkat norma, peraturan, prinsip dan prosedur dalam pembuatan keputusan baik secara tersirat maupun tidak tersirat diharapkan mampu mengatur perilaku aktor baik negara maupun non negara dalam interaksinya. Dengan definisi seperti ini, rezim dapat mempengaruhi perilaku para aktor yang terlibat di dalamnya.

Dalam kasus liberalisasi perdagangan di sektor garam nasional Indonesia, penulis menilai bahwa ada tiga tekanan internasional yang berasal dari rezim global yang dihadapi oleh Indonesia sehingga pada akhirnya meliberalisasi berbagai komoditas strategis. Tekanan tersebut berlaku karena Indonesia masuk menjadi anggota atau meratifikasi perjanjianperjanjian internasional tersebut. Pertama, melalui keanggotaan WTO, kedua melalui penerapan mekanisme SAP oleh IMF, dan ketiga melalui perjanjian-perjanjian FTA dengan beberapa negara.

Bentuk tekanan internasional dari keikutsertaan menjadi anggota WTO adalah akibat yang ditimbulkan dari meratifikasi perjanjian ini. Sebagaimana telah disebutkan bahwa Indonesia kurang mengkaji bentuk perjanjian ini sehingga semakin dirugikan berdasarkan penjelasan sebelumnya. Akan tetapi, Indonesia pun tidak serta merta dapat menutup diri dari rezim perdagangan ini karena merupakan bentuk interaksi Indonesia di dunia internasional. Indonesia sudah meratifikasi perjanjian ini yang dilakukan sesuai dengan kesepakatan bersama. Meratifikasi perjanjian ini bukan bentuk tekanan namun akibat dari ratifikasi inilah yang merupakan bentuk tekanan yang harus dipenuhi oleh pembuat kebijakan. Liberalisasi perdagangan merupakan akibat yang menjadi tekanan 
internasional yang harus dipenuhi oleh pembuat kebijakan menurut teori twolevel games. Sehingga, tarif impor garam pun dikurangi bahkan dihapus menjadi $0 \%$.

Tekanan internasional dari IMF adalah berupa kewajiban Indonesia untuk melakukan deregulasi di berbagai bidang melalui mekanisme SAP. Mekanisme ini merupakan suatu kewajiban yang harus dilaksakan jika Indonesia ingin mendapatkan bantuan dana pada waktu krisis ekonomi tahun 1997 melanda. Salah satu mekanisme adalah liberalisasi perdagangan yang berdampak ke liberalisasi pasar garam domestik. Indonesia pun menandatangai SAP dan melakukan liberalisasi perdagangan. Tingkat Ketergantungan Indonesia (TKI) pun naik dua kali lipat ditahun 1998. Ditahun yang sama, Indonesia mulai mengimpor garam. Kebijakan liberalisasi pasar garam domestik ini juga dibuat untuk memenuhi kewajiban penerapan mekanisme SAP.

Sama seperti keikutsertaan dalam WTO, bentuk tekanan dari perjanjian FTA seperti ACFTA, AIFTA dan AANZFTA adalah akibat dari ratifikasi perjanjian ini yaitu berupa liberalisasi perdagangan yang harus dilakukan oleh Indonesia. FTA dipercaya akan meningkatkan akses pasar diantara negara-negara namun akan menghancurkan UKM. Inilah yang terjadi karena Indonesia kurang dapat menikmati peningkatan akses pasar ini. Garam impor dari Australia, Tiongkok dan India mulai membanjiri pasar domestik sebagai hasil dari perjanjian FTA yaitu liberalisasi perdagangan yang menghapus tarif impor garam menjadi $0 \%$. Kebijakan liberalisasi pasar garam domestik juga dibuat untuk memenuhi perjanjian FTA ini.

Persamaan dari ketiga bentuk tekanan internasional terletak pada tujuannya yang intinya menginginkan liberalisasi perdagangan dengan menurunkan bahkan menghapus bea masuk suatu produk agar produk impor dapat bersaing di pasar domestik negara lain. Hal ini berujung kepada liberalisasi pasar garam domestik Indonesia yang terbukti dengan penurunan hingga penghapusan tarif impor garam menjadi 0\%. Hal ini juga membuktikan teori TwoLevel Games dari Robert D. Putnam yang penulis gunakan sebagai alat analisis kasus impor garam ini bahwa Indonesia mengimpor garam untuk memenuhi tekanan dari dunia internasional. Dengan mengikuti perjanjian dengan rezimrezim global dalam satu sisi menunjukkan bagaimana interaksi aktik Indonesia di dunia internasional 
sehingga tidak memungkinkan untuk menutup diri dari keikutsertaan ini. Akan tetapi, ini berimbas pada kebijakan domestik yang secara otomatis mengikuti isi kesepakatan dari perjanjian yang dalam hal ini adalah WTO, IMF dan FTA.

Tekanan internasional menjadi faktor yang harus dipenuhi oleh pembuat kebijakan. Tekanan ini dapat berupa berbagai hal yang dalam kasus liberalisasi perdagangan di sektor garam nasional. Mekanisme SAP dari IMF wajib diterapkan jika Indonesia ingin memperoleh bantuan dana untuk penanganan krisis dari IMF. Selain itu juga dengan akibat dari ratifikasi perjanjian WTO dan FTA sehingga Indonesia meliberalisasi sektor perdagangan. Secara kronologi, Indonesia turut serta dalam WTO sejak tahun 1995, kemudian ada krisis ekonomi yang melanda Indonesia sehingga pemerintah pada masa itu menerima bantuan dari IMF yang memberlakukan SAP dan yang terakhir akibat Indonesia meratifikasi beberapa perjanjian FTA menjadi faktor-faktor tekanan internasional bagi Indonesia dalam meliberalisasi perdagangan yang dalam hal ini adalah liberalisasi pasar garam domestik.
Kebijakan domestik yang dibuat pun harus kompatibel dengan isi setiap kesepakatan supaya dapat memenuhi perjanjian-perjanjian tersebut. SAP dari IMF, WTO serta perjanjian-perjanjian FTA mengharuskan adanya liberalisasi perdagangan. Segala kebijakan perdagangan Indonesia harus disesuaikan dengan perjanjian-perjanjian tersebut termasuk kebijakan untuk komoditas garam. Ini didukung dengan permasalahan domestik Indonesia sendiri yang mana pemerintah orde baru kurang memperhatikan garam sebagai produk strategis dan sensitif sehingga kebijakan untuk budidaya garam rakyat sangat minim. Hal ini dikarenakan pemerintah pada masa itu hanya memperhatikan komoditas seperti beras dan gula. Hingga kini, garam rakyat dikatakan masih belum berdaya saing jika dibandingkan dengan garam impor. Produksi garam rakyat kemudian dianggap tidak mampu mencukupi kebutuhan konsumsi dan industri sehingga Indonesia pun mengimpor garam.

Penulis menambahkan bahwa permasalahan yang dihadapi Indonesia terkait impor garam adalah pemerintah kurang serius dalam mengkaji segala bentuk kerjasama internasional yang diikuti sehingga industri garam dalam 
negeri kurang dipersiapkan untuk menghadapi serangan garam impor yang deras akibat liberalisasi perdagangan. Produk-produk dalam negeri kurang dapat bersaing juga merupakan akibat dari berkurangnya peran pemerintah akibat mekanisme dalam SAP dari IMF. Selain itu, dalam komoditas garam sendiri, garam domestik masih belum bisa bersaing dengan garam impor dalam hal kualitas, kuantitas serta harga.

Penulis menilai bahwa kebijakan pemerintah yang diambil saat ini berupa impor garamlah yang merupakan kebijakan yang kurang tepat. Impor garam semakin meningkat sementara garam rakyat tidak terserap sepenuhnya. Sehingga akan tepat jika pemerintah mengurangi impor sedikit demi sedikit dan meningkatkan produktifitas petani garam sehingga garam rakyat memiliki daya saing. Garam impor terus masuk dengan harga yang lebih murah semakin mematikan industri garam dalam negeri.

\section{KESIMPULAN}

Sebagai negara memiliki kekayaan laut yang melimpah, Indonesia masih belum mampu memproduksi garam secara maksimal sehingga dalam memenuhi kebutuhan garam domestiknya khususnya garam industri Indonesia harus mengimpor dari negaranegara lain yang sebenarnya tidak memiliki kekayaan laut seperti Indonesia. Impor garam yang semakin meningkat tidak lepas dari praktik liberalisasi perdagangan. Liberalisasi perdagangan di sektor garam nasional merupakan hasil dari tekanan internasional yang berasal dari rezimrezim global yang Indonesia jalankan sejak 1995. Rezim-rezim global mempengaruhi pengambilan kebijakan liberalisasi pasar di Indonesia. Pertama, ratifikasi AoA sebagai salah satu perjanjian dalam rezim perdagangan global, WTO mewajibkan Indonesia melakukan liberalisasi pasar. Kedua, SAP dari IMF yang mewajibkan Indonesia mererapkan skema deregulasi kebiajkan domestik dalam beberapa bidang seperti penghapusan bea masuk (tarif), kuota, serta hambatan lainnya agar memperoleh dana pinjaman dari IMF dalam penannganan krisis 1997-1998. Ketiga adalah ratifikasi beberapa penjanjian FTA dengan negara-negara luar ASEAN seperti ACFTA, AIFTA dan AANZFTA turut berkontribusi terhadap liberalisasi perdagangan di Indonesia yang ditandai dengan menurunnya bea impor bahkan penghapusan bea masuk hingga $0 \%$ untuk berbagai komoditas termasuk garam. Tekanan internasional dari tiga rezim membuktikan teori Two Level Games dan terbukti menjadi jalan 
masuknya garam impor (industri) dalam jumlah yang melimpah dari berbagai negara-negara lain sehingga membanjiri pasar domestik Indonesia. Sementara itu, di sisi lain garam rakyat atau lokal masih belum bisa bersaing dengan garam industri dari luar negeri baik dari kualitas, kuantitas maupun harga.

\section{Daftar Pustaka}

Abbott, Kenneth W. dan Snidal, Duncan. (2000). Hard and Soft Law in International Governance. International Organization, Vol. 54, No. 3.

Apriella, Nanda. (2016). Dampak Program Pemberdayaan Usaha Garam Rakyat (pugar) Terhadap Strategi Nafkah dan Pendapatan Rumah Tangga Petambak Garam. Bogor: Insitut Pertanian Bogor.

Ariyanti, Fiki. (14 Oktober 2013). Daftar Lengkap 29 Komoditas Pangan yang diimpor RI. Liputan6.com. diaksed dari <http://bisnis.liputan6.com/read /719523/daftar-lengkap-29komoditas-pangan-yang-diimporri>

Baihaki, Lukman. (2013). EkonomiPolitik Kebijakan Impor Garam Indonesia Periode 2007-2012, Yogyakarta: Fisipol UGM.
Banton, Caroline. (2019). Trade Liberalization. Investopedia. diakses dari $<$ https://www.investopedia.com/ terms/t/trade-liberalization.asp> Delforge, Isabelle. (2005). Dusta Industri Pangan: Penelusuran Jejak Monsanto. Yogyakarta: Insistpress.

Glipo, Arze. (2003). The WTO-AoA: Impact on Farmers and Rural Women in Asia. World Trade Organizations Documents. diakses dari

<http://www.glowboell.de/media /de/txt_rubrik_5/sus_arze_ruralw omen.pdf>

Kementerian Kelautan dan Perikanan. (2018). Refleksi 2017 dan Outlook 2018 Membangun Dan Menjaga Ekosistem Laut Indonesia Bersama Ditjen Pengelolaan Ruang Laut. diakses dari <https://kkp.go.id/djprl/artikel/ 2798-refleksi-2017-dan-outlook2018-membangun-dan-menjagaekosistem-laut-indonesiabersama-ditjen-pengelolaanruang-laut>

Kementerian Keuangan. (2012). Free Trade Agreement (FTA) dan Economic Partnership Agreement (EPA) dan Pengaruhnya terhadap 
Arus Perdgaangan dan Investasi dengan Negara Mitra. diakses dari

<http://www.kemenkeu.go.id/sit es/default/files/kajian.pkrb_.fta_. 2012.pdf>

Kementerian Perindustrian. (2009). Peta Panduan (road map) Pengembangan Klaster Industri Prioritas Industri Kecil dan Menengah Tertentu Tahun 2010 $2014 . \quad$ diakses dari <http://rocana.kemenperin.go.id/ index.php/download/category/1p?download $=6 \% 3 \mathrm{Ap}-\mathrm{p}>$

Kementerian Perindustrian.

November 2015). Impor Garam Industri Tidak Kena Bea Masuk. diakses dari <https://www.kemenperin.go.id/ artikel/13466/Impor-GaramIndustri-Tidak-Kena-Bea-Masuk>

Khudori. (2004). Neoliberalisme Menumpas Petani: Menyingkap Kejahatan Industri Pangan. Yogyakarta: Resist Book.

Krasner, Stephen D. (1983). International Regimes. Ithaca, New York: Cornell University Press.

Nurhayat, Wiji. (2014). Mulai 1998, RI Impor Garam dari Australia, AS dan India. Detikfinance. diakses dari <http://finance.detik.com/read/2 014/03/25/135657/2535943/10 36/mulai-1998-ri-impor-

garamdari-australia-as-dan-india> Oatley, Thomas. (2012). International Political Economy Sixth Edition. Longman: Pearson Education Pelawi, F, Josep. (2007). Retaliasi Dalam Kerangka Penyelesaian Sengketa WTO. Buletin Kementrian Perdagangan Republik Indonesia. Edisi 46.

Putnam, R. D. (1988). Diplomacy and Domestic Politics: The Logic of Two-Level Games. International Organization. Vol. 42. No. 3.

Razif. (2012). Organisasi Terputus dengan Sejarah. Majalahsedane. diakses

dari <http://www.majalahsedane.net/ 2012/08/organisasi-terputusdengan-sejarah.html>

Sandi, Ferry. (13 Januari 2020). Miris!Impor Garam 2020 Bengkak, Garam Lokal tak Terserap. CNBC Indonesia. diakses dari <https://www.cnbcindonesia.com /news/20200113130522-4-

$\underline{129562 / \text { miris-impor-garam- }}$

2020-bengkak-garam-lokal-takterserap>

Rochwulaningsih, Yety. (2012). Pendekatan Sosiologi Sejarah 
pada Komoditas Garam Rakyat:

dari Ekspor Menjadi Impor.

Paramita: Historical Studies

Journal. Vol.22. No.1 (2012).

Serikat Petani Indonesia. (2011).

Perjanjian Perdagangan Bebas;

Malapetaka Bagi Petani Kecil.

diakses

dari

$<$ https://spi.or.id/perjanjian-

perdagangan-bebas-malapetaka-

bagi-petani-kecil/>

Setiawan, Dikky. (1 Desember 2013).

WTO Jadi Ancaman Swasembada

Pangan

Indonesia.

TribunNews.com. diakses dari

https://industri.kontan.co.id/new

s/wto-jadi-ancaman-

swasembada-pangan-indonesia/

Setiawan, Sigit. (2013). ASEAN-China

FTA: Dampaknya Terhadap

Ekspor Indonesia dan Cina.

Kementerian Perdagangan.

diakses

dari

<http://www.kemendag.go.id/file

s/pdf/2013/06/26/-

1372216618.pdf>

Sulaiman. (15 Januari 2013). Liberalisasi

Perdagangan WTO Pengaruhi

Swasembada Pangan Indonesia.

Lampost.co. diakses dari <http://lampost.co/berita/liberal isasi-perdagangan-wto- pengaruhi-swasembada-pangan-

indonesia>

Taufikurohman, M. Rizal. (Desember 2016). Laporan Akhir Kajian Dinamika Lingkungan Strategis dalam Pembangunan

Kemaritiman. Kementerian

Koordinator Bidang

Perekonomian. diakses dari <http://info.trilogi.ac.id/repositor y/assets/uploads/AGB/3d5fdlaporan-akhir_kajian-dinamikastrategi-kemaritiman-rev-rizal.pdf $>$

Tempo.co. (15 Februari 2013). Indonesia Didesak Keluar dari WTO. diakses dari

$<$ https://bisnis.tempo.co/read/46

1628/indonesia-didesak-keluardari-wto/full\&view=ok>

Website: <https://comtrade.un.org/>

World Trade Organization. Principles of the Trading System. diakses dari <https://www.wto.org/english/t hewto e/whatis e/tif e/fact2 e.ht $\underline{m}>$

\section{Data Wawancara:}

1. Wawancara penulis dengan beberapa petani garam NTT

2. Wawancara dengan Ibu Esterlina F. staf bidang koperasi Dinas Koperasi dan Usaha Mikro Kecil 
Menengah di Kupang, NTT pada 09 Oktober 2014 